\title{
The Giving Punishment of School Rules Violation in Enforcing Discipline Characters on MTs. Raudlatussa'adah Pontianak
}

\author{
Rianawati1,a*, Nurhamid1,b \\ 1State Islamic Institute (IAIN) Pontianak, Indonesia \\ a irin_ptk@ymail.com; b hhamid960@gmail.com \\ Whatsapp Number [082148263025]
}

How to Cite: Rianawati \& Nurhamid. (2020). The Giving Punishment of School Rules Violation in Enforcing Discipline Characters on Mts. Raudlatussa'adah Pontianak. International Journal for Educational and Vocational Studies, 2(2), 151-157. DOI: https://doi.org/10.29103/ijevs.v2i2.2132

\section{ARTICLE HISTORY}

Received:13 November 2019

Revised: 22 December2019

Accepted: 4 February 2020

\section{KEYWORDS}

Punishment;

Violation;

Upholding the Character;

Discipline;

\begin{abstract}
This research is motivated by the recent most cases of rule violations conducted by a number of students in MTs. Raudlatussa'adah Pontianak. From the results of observations and initial documentation of the research, the forms of violations that are often done by students are late, wearing needless uniforms, long hair, inappropriate hair cut for students, fighting and other forms of violations. Even though MTs. Raudlatussa'adah Pontianak has made written rules including the threat of sanctions / penalties for the perpetrators. Based on the background of the problem, the researcher then conducted further research in order to explore and analyze information about how the act of giving penalties in cases of school rules violations in order to uphold the character of students. The approach and method used in research is a qualitative approach with descriptive methods, that this study seeks to describe the phenomenon in accordance with the facts occurred in the field. Furthermore, the subjects in this study include: Principal of Madrasah, Deputy Head of Madrasah for Student Affairs, Teachers of Islamic Character and students. For data collection researchers used in-depth interview techniques, non-participant observation and study documentation. The data processing and analysis techniques used consist of data reduction, data presentation and conclusions. Meanwhile, to check the validity of the data, researchers used triangulation techniques. Based on the explanation and analysis of the research data, it can be concluded that the preparatory step for the punishment of school rules violations in an effort to uphold the character of student discipline is done by verbalizing the punishment in the Student Orientation Period (MOS) activities, flag ceremonies and through classroom wall magazines and billboards. . As for the implementation of the punishment given by the teacher, but it is not consistent with the existing rules and the implementation also does not contain educational elements.
\end{abstract}

This is an open access article under the CC-BY-SA license.

\section{INTRODUCTION}

The character of discipline and discipline is very important in encouraging the achievement of the productivity of an organization. This function is also closely related to efforts to direct and develop human resources that are carried out effectively and efficiently in carrying out their rights and obligations based on obedience to collective agreements. Not only in organizations, enforcement of discipline should also be carried out on students in schools especially Islamic educational institutions which in this case are madrasah. As a national education subsystem, madrasah also has the aim to form people who believe and devote to God Almighty. This goal is then spelled out in a number of rules, one of which is the school code of conduct.

The rule that has been made by the madrasah, is one form of decisive actions such as punishment with the aim of upholding student discipline. The use of punishment in violation of school rules basically aims to provide a deterrent effect for the perpetrators of disciplinary action towards what is the purpose of the madrasah, so that it is expected to be an example for others and for the perpetrators no longer repeat the same mistakes. Therefore, it should be appropriate if the punishment should also be adjusted to the level of age, error rate and nature of the error.

Punishment is a logical consequence in order to weaken deviant behavior. Punishment also prevents repetition of unexpected behavior, strengthens self-motivation and becomes a habit of continuing to behave positively. The giving of punishment in madrasah which in this case is carried out by the teacher certainly is not done carelessly, but must implement through various considerations and have been agreed between the rules maker (school committee, school principal and teacher) and parents of students.

Enforcement of the rules is very necessary if the situation is considered to have saved from the usual, violating moral values or has led to criminals. Because it 
could, if left unchecked it would affect himself and others. Although punishment is legalized in all its forms and types legalized in the practice of Islamic education. But there are a number of requirements that must be met. In opinion, the punishment that is carried out should be a form of punishment that seeks to build discipline in the learning process and in everyday life.

Establishing discipline is not an easy process because punishment is apparently not always as effective as happened in MTs. Raudlatussaadah Pontianak. From the results of observations and initial documentation of the study, the forms of violations that are often done by students are arriving late, wearing less neat uniforms, long hair, hair cut with a model that is inappropriate for students, fighting and other forms of violations. Even though MTs. Raudlatussaadah is one of the private MTs in urban areas, in addition there are also several other schools that are quite close such as Al-Anwar MTs, SDN 10 and SDN 02. This Madrasah also has been established for a long time, namely since December 22, 1992. Besides that, Madrasah, it claims to be one of the madrasah that upholds a discipline attitude based on various disciplinary points that are enforced. In addition, teachers of the Islamic Education (PAI) are professional teachers. This is proved by the educator certificate held by PAI teachers.

Broadly speaking, punishment is a consequence of violations of rules which are done by individuals or groups. The researcher used a number of theories from experts discussing the definition of punishment, including $\mathrm{M}$. Ngalim Purwanto (2000:186) which states that punishment is suffering that is inflicted or intentionally caused by someone after a crime violation. Meanwhile, according to Mahmud (2013: 76) punishment is a learning method used to correct mistakes and personality and can be used as lessons for others around him.

Punishment in education is a strict and appropriate educational tool, so that in its implementation a punishment can be applied as an educational tool in the event of a violation or error committed by students with the aim of the student being able to correct his actions (Abu Muhammad Iqbal, 2013: 174). Furthermore, when viewed from the form of punishment, Armai Arief (2002: 130) argues that punishment in education contains two meanings, namely the first, the most unpleasant and preventive and repressive tools. Second, rewards from unpleasant actions from students. Meanwhile, Kartini Kartono (1992: 126) states that punishment is an act that is given to cause suffering physically and mentally, directed to arouse the conscience and conscience of the sufferer or the offender.

Even though punishment is permitted, there are also group of education that refuse this. Behavioristic flow assumes that punishment can reduce the frequency of responses to stimuli that are forced to be condemned because they are a unified whole. This flow figure, BF Skinner (1980) offers negative reinforcement instead of punishment because based on his research, the response to reinforcement is higher than the response to punishment (Jeanne Ellis Ormrod, 2009: 454).

According to Ngalim Purwanto (2000: 238) in general, the theory of punishment is divided into 5 (five) parts, namely: the theory of retribution and compensation, the theory of corrective punishment, the theory of protection punishment, the theory of punishment for compensation, and the theory of frightening punishment. First, the theory of retribution and compensation. This theory is less relevant to be used in education because it is more suitable to be applied in the life of the nation and state. Therefore, researchers will only explain a little about these two theories.

The theory of retaliation says that punishment is used to avenge someone's wrongdoing. Second, the compensation theory says that punishment is given in order to compensate violations. Third, the theory that is appropriate with the world of education is the theory of improvement, this theory says that punishment is given so that violators are aware of violations / mistakes that have been made so that awareness arises to correct their actions so as not to make the same mistake a second time. Fourth, the next theory is the theory of protection, this theory says that punishment is given to protect the public from violations committed by perpetrators. The link in the world of education, punishment is given to protect other students violations committed by students who violate school rules. Fifth, the last theory is the theory of frightening punishment.

This theory reveals that punishment is given to instill fear in the offender so that he is reluctant to commit the offense again due to the fear that arises from the punishment received by the offender. From several theories above, the researcher concludes that punishment is a firm and conscious action by someone (in formal education means teacher) that functions as a tool or method used to correct and or prevent the same mistakes from repeating as well as to improve the mental attitude of participants students. Besides that, it needs to be emphasized that punishment is not a means for teachers to hurt or retaliate against students.

\section{METHODS}

This study uses a qualitative approach, which is a research procedure that produces descriptive data in the form of written or oral words from people and observable behavior. The qualitative approach emphasizes the meaning, reasoning, definition of a particular situation, more research in everyday life (Lexy J Moleong, 2004: 13).

Researchers used a qualitative approach aimed at obtaining data or information about opinions, thoughts and judgments about giving penalties for violations of school rules in an effort to enforce discipline in MTs. Raudlatussaadah Pontianak. Furthermore, the method used by researchers is a descriptive method, where this study seeks to describe social phenomena as they are. This is as stated by Robert Bodgan and Steven J. Taylor (1993: 142). This method is used because researchers want to provide an overview of the phenomenon in the field. In addition to uncovering the facts about the object under study as it is.

Based on theory, the researcher describes this research as a whole by analyzing phenomena, events, activities, social, attitudes, perceptions of people individually or in groups, both data obtained through observation, interviews and documentation. Some of these descriptions are used to find principles and explanations that lead to conclusions 
relating to the punishment for violating school rules in an effort to uphold the character of discipline in MTs. Raudlatussa'adah Pontianak.

\section{RESULTS AND DISCUSSIONS}

\subsection{Preparation of Punishment for Violating School Rules in Efforts to Enforce Student Discipline at Mts. Raudlatussaadah Pontianak}

\section{a. Introduction and Understanding Phase}

The introduction and understanding phase is the earliest stage undertaken by MTs. Raudlatussa'adah Pontianak in socializing madrasah rules. Both relating to student obligations, restrictions and sanctions that apply in the school. Here the researchers found that the introduction of school sentences was carried out in a number of ways, namely by verbal communication during the Student Orientation Period (MOS), socialization when students carried out flag ceremonies, through billboards that were posted in front of the school and through slides posted on the wall magazines of all classes.

At the stage of understanding students are given the opportunity to independently find out everything related to school penalties, but the facts that occur on the ground it turns out students are reluctant to look for more information about obligations, prohibitions, and sanctions that apply in schools. Here students are only limited to listen from what the teacher delivered during the orientation and flag ceremony. the punishment in front of the school and even in class they don't read. This is different from what was conveyed by Soedijarto (2013: 253) which explains that in the introduction phase of punishment students should be introduced or socialized early on what are the rules that apply both from the disciplinary aspects and aspects of the punishment that will be obtained if students violate the order. Furthermore, at the stage of understanding, on the basis of students' curiosity, he will automatically find out all the components of the order so that he will understand every consequence of his actions in school.

Based on the above explanation, it can be understood that the stage of introduction of punishment carried out by the madrasa is appropriate and in accordance with the theory, but at the stage of understanding students are less active because it is proven they are not looking for other further information than what has been delivered by the teacher during the orientation period and when flag ceremony.

\section{b. Acceptance phase}

Acceptance is a learning approach that allows students to be part of the madrasa community who must comply with all the penalties contained in the madrasa, so that initially the punishment is still in the form of a long appeal that will be a matter of thought that eventually he will feel the impact of acceptance or rejection of values the discipline found in the school rules. In other words, students understand that they will receive punishment if they are not disciplined in carrying out discipline in school. At the admission stage students can ask, accept, reject, propose, and observe the teacher's activities. Instead the teacher should show disciplinary behavior in order to become a habit and exemplary for students (Soedijarto, 2013: 254).

The fact, researcher found that students accept all the contents of school rules, especially punishment with a "unanimous" without any questions, statements or proposals. Thus they indirectly agree or accept all points contained in their school. At this stage of acceptance the teacher has also become a good example for students because the teacher enters and arrives on time, is well-dressed and speaks politely. From this, it follows that the acceptance stage is well implemented and in accordance with the theory even though students are less active in criticizing the applicable penalties and must obey them while in the school environment.

\section{c. Integration Stage}

Based on the results of observations of researchers in the field, researchers found that it turns out that the values of punishment in madrasa are also obeyed by many students not only when they are in class, but also when they are in extracurricular activities such as when praying in congregation, health gymnastics, and various other activities. In addition, students also integrate these values when they break and face the teacher outside of class time.

At this stage students actually begin to incorporate the value of discipline contained in the school discipline into the overall value system adopted. Therefore, this stage is determined by the effort in the stage of introduction, understanding, and acceptance stage. After this stage is implemented, students will integrate the value of discipline in daily activities at school such as in learning activities, extracurricular activities, hanging out with friends, and talking with teachers (Soedijarto, 2013: 255). Based on this it means that in general students have integrated the values of the discipline contained in the school order into various school activities and this stage has been implemented well.

\section{d. Types of Violations in Schools}

Jensen (in Sarlito, 1994: 209-210) divides the forms of school order violations into four parts namely: (1) Delinquency which causes physical casualties to others, such as fights between students. (2) Delinquency that causes material casualties such as destruction of school infrastructure/equipment, extortion of other students, theft of friends' belongings, school-owned teachers, and others. (3) Social delinquency that does not cause casualties on the part of others such as smoking in the school environment. (4) Delinquency that goes against status, for example as a student often plays truant, as a child against parents, against teachers, against school officials and others.

Based on observations and documentation results in the field, the forms of violations that have been done by 
students in the form of ditching, arriving late, fighting, returning prematurely, committing violence to one of my classmates, denying the teacher when advised, long hair, inappropriate hairdo with the school environment, not doing assignments, not taking notes, bringing mobile phones to school, smoking at rest hours in the cafeteria.

From the explanation above, the violations that have been done by students in MTs. Raudlatussa'adah Pontianak, including the type of delinquency that causes physical casualties, delinquency that does not cause casualties on the other party, and delinquency that is against status.

\section{e. Reasons Students Violate}

Based on the results of the study found data that some of the reasons students violate the rules in the madrasa is due to several reasons such as being late in class because his house is far away, cutting hair in an inappropriate style because of the bandwagon, and those who are reluctant to read the rules in school. In addition, there are teachers who lack discipline, bad relationships / environment, there are teachers who do not give action to students who violate the rules of madrasa, they still bring bad habits from outside the school environment or from home.

Similar opinion is said by Tulus (2004: 53) other causes of disciplinary violations include: (a) Good planning, but the implementation is poor and not monitored by the school principal; (b) The application of an inconsistent and inconsistent discipline; (c) Lack of support and participation of parents in handling school discipline, especially students with problems; (d) Many students at the school come from problem students in self-discipline. They tend to violate and ignore the school rules.

\subsection{Execution of Punisment for Violating School Rules in Efforts to Enforce Student Discipline at Mts. Raudlatussaadah Pontianak}

\section{a. Types and Forms of Punishment}

Logical Punishment, where the child is punished so that he experiences suffering that has a logical relationship with his mistakes. This logical punishment is used on older children who are able to understand the relationship between the mistakes they make and the punishment they received (Suwarno, 1992: 177).

Ag. Soejono (1980: 169) put forward the form of punishment in three forms, namely: (1) Form of Cue, the rectification effort we do in the form of facial cues and other limbs. For example, there is a student who is doing something wrong, for example playing with teasing his sister. Educators look at him with a grim expression which indicates that he does not approve of students doing so. He shook his head and moved his hands as a sign for students to leave his sister. If students because of their preoccupation do not see that the educator is looking at him, then the educator gives a preliminary gesture by clapping to attract his attention; (2) The form of words, signs in the form of words can contain warning words, words of reprimand and finally threatening words. If necessary the form of signs is replaced with words in the form of warning words, mentioning the name of the naughty child in a short, firm voice, for example "Amir ..!". (3) The form of acts, rectification efforts in the form of actions are heavier than the previous effort. Educators impose on students who do wrong, an act that is not pleasing to him or he prevents students from doing something that becomes his pleasure.

In the field, researchers found that the punishment given by the teacher to students began with several stages, namely: (1) clarification, (2) verbal reprimand with gentle, (3) stern warning that if students do not correct their mistakes will be acted firmly, making statements in writing not to repeat the same mistakes, (4) Assignments such as cleaning trash in the school yard, cleaning students and teachers' restrooms, memorizing short letters, reading verses of the Koran, respecting the flag while singing Indonesian Raya songs, (5) Summoning parents / guardians of students, suspension, (6) Returning students to parents (drop out).

From the explanation above it can be seen that the type of punishment given to students who violates the school rules at MTs. Pontianak Raudlatussa'adah is a type of logical punishment in which students understand the relationship between the punishment received and the violations committed. The form of the punishment is the form of cues, forms of speech and forms of deeds. This punishment is similar to the results of Yuyun Wijayanti's research (2008) which states that a form of refressive punishment is carried out after the child has made a mistake, normative punishment because the punishment aims to improve the morale of students, logical punishment because the punishment is given for bad deeds.

\section{b. Punishment Method}

The method of giving penalties carried out by school principals, deputy heads of student affairs and moral subject teachers of MTs. Pontianak Raudlatussa'adah as a form of sanctions contained in the rules that apply in the school in the form of clarification, reprimand, assignment, temporary dismissal, and finally returning students to parents.

According to al-Ghazali (in Abu Muhammad Iqbal, 2013: 180) the punishment must implement through several stages. First, if students make mistakes the first time the teacher should let the offender have the opportunity to correct their mistakes. Second, giving a reprimand or stern warning to the offender with a note that it should not be done in public to prevent him from criticizing other students. Third, the granting of physical law is the last resort if the perpetrator repeats the violation, but this physical punishment must not injure the students.

According to al-bdAbdari (M. Arifin, 2003: 158) punishment in education should begin with clear research 
on the perpetrators of violations because it is not uncommon for students to make mistakes intentionally in order to get the attention of the teacher. Furthermore, physical punishment should not be too hard as the use of a stick to hit students who are just learning to understand the rules (new students). The punishment must also be adjusted to the severity and severity of the violation. Thus the method used by MTs teachers. Raudlatussa'adah Pontianak as a madrasa which is actually an Islamic educational institution is in accordance with the theory of Islamic education figures al-Abdari and al-Ghazali.

\section{c. Factors Inhibiting the Punishment in Schools}

Some of the causes of obstruction of the application of punishment in MTs. Raudlatussa'adah Pontianak is the understanding of parents who do not understand, enforcement of small mistakes and are not implemented consistently. In addition, some students do not understand that reprimands are part of the punishment so students only smile when the teacher reprimands them, lack of awareness of students also influences such as when teachers give summons students do not deliver it but they throw it away or they hide it in a bag or under bench, the existence of a teacher who lacks discipline, the teacher is not consistent in giving punishment.

A similar opinion was conveyed by E. Mulyasa (2008: 26) that disciplinary enforcement is often caused by irrelevant teacher actions that will inhibit students' self-discipline including (1) often criticizing student work without providing solutions, (2) giving assignments but never giving feedback back, and (3) punishing without giving an explanation of student mistakes results in the enforcement of discipline being less effective, damaging the personality and self-esteem of students.

The inhibiting factor for the punishment that arises from students can be in the form of the assumption that the punishment given by the teacher is a ransom or elimination of mistakes made by students so that students feel free from their violations and are no longer afraid to commit violations again. Another factor is that students consider a mild punishment in the form of a rebuke given by the teacher is not a severe punishment and made an impression in themselves so that students consider the reprimand is just an ordinary advice or not a punishment. Furthermore, another factor that causes obstacles to the punishment is that students assume that discipline is not a collective agreement but as a binding on freedom and pressure for students so that students feel challenged to break them. In addition, another factor is the lack of student awareness to obey the rules in the form of school rules.

From some of the facts mentioned above, the researcher can explain that the causes of obstruction of punishment in schools can be caused by teachers, students and parents/guardians of students.

\subsection{The Impact of Punishment on School Code Violations in Efforts to Enforce Student Discipline in MTs. Raudlatussaadah Pontianak}

Penalties in an effort to enforce discipline can theoretically have positive and negative impacts.

\section{a. Positive Impact of Punishment}

Penalties given by teachers to students who violate school rules in MTs. Pontianak Raudlatussa'adah has a good impact on students in a number of ways that can increase student attention in the learning process, can increase learning motivation, develop children in the learning process, can control and modify the behavior of children who are not good, encourage the emergence of productive behavior, can strengthen the willingness of students to do good.

The above situation turns out to be in line with the opinion of Marno and M. Idris (2009: 133) that the provision of punishment if carried out in the right way and principle can effectively achieve the purpose of its use. Some of the objectives of punishment include: (a) Increase student attention in the learning process, (b) Generate, maintain, and increase student motivation, (c) Direct the development of students' thinking towards divergent thinking (d) Organize and develop their own children in the learning process (e) Controlling and modifying the behavior of students who are less positive and encouraging the emergence of productive behavior.

Another opinion was expressed by M. Ngalim Purwanto (2000: 187) that punishment can have a positive impact in the form of (1) Improving the behavior of the offender because he feels guilty for his wrongdoing. (2) Strengthening the offender's offense to do good. Similar results were also found in the results of the study of Muhammad Said Fadhori (2010) with the result that the granting of punishment to students can foster a sense of discipline in students can foster student discipline. This is evidenced by the value of the percentage of the effect of punishment on discipline with a yes or agree answer of $72.41 \%$.

\section{b. The Negative Impact of Punishment}

As the researcher has explained before, that punishment can also have bad consequences for the recipient of the sentence (students). The same thing happened in MTs. Raudlatussa'adah Pontianak, the principal and his deputy said the possibility of students having a sense of revenge, good at hiding mistakes, and felt they no longer had mistakes after receiving the punishment given by the teacher.

The results of this study differ from the results of the study of Maria Ulfa (2008) which says that the punishment given at the Muhammadiyah Yogyakarta Muhammadiyah Madrasa can have a negative impact in the form of feelings of making amends or violating the discipline by serving the sentence given by the teacher. 
M. Ngalim Purwanto (2000: 189) argues that punishment can have an impact (a) Cause feelings of revenge on the convicted. this is the result of arbitrary and irresponsible law. Such consequences must be avoided by educators. (b) Causing children to be better at hiding violations. This is also a result that is not good, things that is not expected by educators. (c) Causing the offender to lose his guilt, because the offense is deemed to have been paid for with the sentence he has suffered.

\section{CONCLUSION}

Based on the discussion of the results of the study it can be concluded that the administration of punishment is quite good in its preparation and impact but not good in its implementation. The conclusion is based on the answers to the following research questions:

1. Preparation of punishment for violating school rules in MTs. Raudlatussa'adah at the introduction stage was very good starting from the socialization during the Student Orientation Period (MOS), socialization during the flag ceremony, socialization during lesson hours, socialization through billboards, socialization through wall magazines. At the stage of understanding students tend to be less critical because they are not looking for more information about school rules, even though the points are verbally socialized by the teacher that are not every day and only a few points are raised. at the admission stage students also tend to be passive and accept school punishment for what it is without giving questions, statements or input. At the integration stage students integrate the character of discipline into every activity in the school. There are three types of violations committed by students in schools, namely delinquency which causes physical casualties, delinquency does not harm others, acquaintance against status. The cause of students committing an offense is obtained from three elements namely the teacher, the environment and students themselves.

2. The implementation of punishment for violating school rules in an effort to uphold the discipline character of students in MTs. Pontianak Raudlatussaadah is in accordance with the sanction points contained in the madrasa rules, the type of punishment used is a type of logical punishment, the form of punishment there is a gesture, words, and deeds. The method of providing punishment is through several stages starting from clarification then warning / reprimand, then the assignment then the temporary dismissal and finally returning to the parents / guardians of students. Types, forms, and methods of giving punishment are good enough but the implementation of punishment is not consistent so that students' discipline is not good because there are teachers who punish but there are also teachers who do not give any action to students who violate school rules. Some other factors that hinder the implementation of the punishment partly understanding of parents who do not understand, enforcement of small errors that are inconsistent sometimes punished but sometimes not, some students do not understand that reprimand is part of the punishment so students only smile when the teacher reprimands, lack of awareness of students also have an effect such as when the teacher gives a summons, the students do not deliver it but they throw it away or hide it in a bag or under the bench, there are teachers who lack discipline, the teacher is not consistent in giving punishment.

3. Impact of punishment for violating school rules in an effort to uphold the character of student discipline in the MTs Raudlatussaadah Pontianak. Penalties in an effort to enforce discipline can have positive and negative impacts. The punishment given by the teacher to students has an impact on increasing student attention in the learning process, increasing motivation to learn, developing students in the learning process, being able to control and modify student behavior that is not good, encouraging the emergence of productive behavior, can strengthen the willingness of students to follow rules. But the negative impact is not good for the recipient of punishment (students). Like what was said by the headmaster and his deputy that the impact of the implementation of the punishment that can cause feelings of revenge, good at hiding mistakes, and feel no longer has an error after receiving the punishment given by the teacher.

\section{REFERENCES}

Abu Muhammad Iqbal. (2013). Konsep Pemikiran Al-Ghazali Tentang Pendidikan. Madiun: Jaya Star Nine.

Ag Soejono. (1980). Pendahuluan Ilmu Pendidikan Umum. Bandung: CV. IImu.

Armai Arief. (2002). Pengantar IImu dan Metodologi Pendidikan Islam. Jakarta: Ciputat Press

E. Mulyasa. (2008). Standar Kompetensi dan Sertifikasi Guru. Bandung: Remaja Rosda Karya

Henry N Siahaan. (1986). Peranan Ibu Bapak Mendidik Anak, Bandung: Angkasa

Jeanne Ellis Ormrod. (2009). Educational Psychology Developing Learners (Sixth Edition). Jakarta: Erlangga

Kartini Kartono. (1992). Patologi Sosial II Kenakalan Remaja. Jakarta: Rajawali

Lexy J Moleong. (2004). Metodologi Penelilian Kualilatif. Bandung: Remaja Rosdakarya

M. Ngalim Purwanto. (2000). Ilmu Pendidikan Teoritis dan Praktis. Bandung: CV. Rosda Karya

Mahmud. (2013). Paradigma Pendidikan Anak dalam Islam. Bandung: Pustaka Setia

Maria Ulfa. (2008). Penerapan Hukuman Siswa di Madrasah Muallimaat Muhammadiyah Yogyakarta. Skripsi Program Studi Pendidikan Agama Islam, Fakultas Tarbiyah Universitas Islam Negeri (UIN) Sunan Kali Jaga Yogyakarta.

Marnodan M.Idris. (2009). Strategi dan Metode Pengajaran, Jogjakarata: Ar-RuzzMedia.

Muslim. (1990). IImu Pendidikan. Semarang: Fakultas Tarbiyah Institut Agama Islam Negeri (IAIN) Walisongo

Robert Bodgan dan Steven J. Taylor. (1993). Kualitatif Dasar-dasar Penelitian (diterjemah oleh A. Khosim Apandi). Surabaya: Usaha 
Nasional.

Sarlito Wirawan Sarwono. (1994). Psikologi Reinaja. Jakarta: RajaGrafindo Perkasa.

Soedijarto. (2013). Landasan dan Arah Pendidikan Nasional Kita. Surabaya: Kompas Media Nusantara

Tulus Tu'u. (2004). Peran Disipiln pada Prilaku dan Prestasi Siswa. Jakarta: PT. Grafindo Widia Sarana Indonesia.

Yuyun Wijayanti. (2008). Model Hukuman dalam Upaya Membentuk Kedisiplinan Siswa di Madrasah Salafiyah III Krapyak Yogyakarta. Skripsi Program Studi Pendidikan Agama Islam, Fakultas Tarbiyah Universitas Islam Negeri (UIN) Sunan Kali Jaga Yogyakarta. 